\title{
NERVAL, POETA DO RENASCIMENTO
}

\author{
Jean-Nicolas llLouz
}

Universidade de Paris VIII

Resumo

Em 1830 Nerval publica uma Antologia de poemas de Ronsard

(...) que, juntamente com a Antologia de poemas alemães, do mesmo ano, constitui um díptico no qual se apresentam as duas faces de um manifesto por uma poesia popular, nacional - e romântica. A inspiração renascentista se prolonga na própria escrita nervaliana: nas Odelettes, recordação de uma época na qual Nerval "ronsadizava"; nos sonetos das Quimeras [Chimères] nos quais Nerval "solda" o seu verso a partir do verso de Du Bartas; na prosa de Sylvie, narrativa ligada ao Sonho de Polifilo de Francesco Colonna, embora a novela nervaliana nos faça adentrar um universo literário no qual a alegoria renascentista já não pode mais funcionar tão eficazmente.

Abstract

In 1830 Nerval published an Anthology of Poems from Ronsard (...) which, next to his Anthology of German Poems, issued in the same year, form a diptych where the two sides of a manifesto for a popular and national poetry - for a romantic poetry. The Renaissance inspiration also continues in Nerval's own style of writing, which can be traced in his Odelettes, recollections from a time when Nerval "ronsardisait"; in some of his sonnets from Chimera [Chimères] in which Nerval "welded" his verses from Du Bartas'; and in the prose style of Sylvie, a narrative strictly connected with Polifilo Dream by Francesco Colonna, although the Nervalian novelette plunges the reader in a literary universe where the Renaissance allegory can no longer work so efficiently.

\author{
Palavras-chave \\ Gérard de \\ Nerval, poesia \\ francesa, \\ Romantismo, \\ Renascimento.
}


assumindo um "ar acadêmico", 1 o qual mais tarde ele irá ironizar ao retomar seu estudo sobre Les poètes $d u X V^{e}$ siècle em La Bohême Galante, que Nerval (que nessa época assinava apenas Gérard) se debruça sobre o Renascimento. Depois de ter publicado em 1830, na "Bibliothèque choisie", uma coletânea de Poésies allemandes, no mesmo ano e na mesma coleção ele publica um Choix de poésies de Ronsard [Antologia de poemas de Ronsard], confirmando assim a reputação adquirida na cena literária de sua época: a de um "literato" - "o mais cultivado de todos", escreverá Gautier - atento a todas as questões literárias que agitam a época e que, depois de ter se destacado como um dos principais introdutores da literatura alemã na França, participa então da descoberta romântica dos poetas da Pléiade.

É verdade que, considerando as coisas apenas desse ponto de vista, Gérard chega com algum atraso no debate; e a argumentação que ele desenvolve em sua Introduction, na qual segue Sainte-Beuve bastante de perto, faz eco aos debates que a "questão Ronsard" já suscitara não apenas no campo da história literária propriamente dita, mas sobretudo na atualidade do batalha a favor (ou contra) o romantismo.

Em sua tese intitulada Mort et réssurrection de la Pléiade [Morte e ressurreição da Pléiade], Claude Faisant mostrou como a reabilitação de Ronsard de fato põe em jogo poderosas questões estéticas e ideológicas, capazes de acirrar os ânimos - a três séculos de distância - não apenas de clássicos e românticos, mas ainda de fazer aparecer entre os primeiros e os segundos a reversibilidade de posições em aparência inteiramente inconciliáveis. Ainda que o declínio de Ronsard tenha acompanhado, em negativo, a formação e o surgimento da doutrina clás-

${ }^{1}$ La Bohême Galante, NPl III, p. 243. A abreviação NPl, sequida da indicação do tomo, refere-se à edição das Oeuvres complètes de Nerval sob a direção de Jean Guillaume e Claude Pichois (Paris, Gallimard, 1984-1993, "Bibliothèque de la Pléiade"). 
sica, sua redescoberta não foi conduzida, no século XIX, pelos românticos: estes, pelo contrário, repreendiam Ronsard e sua escola por terem subordinado a poesia à imitação da Antiguidade e por terem participado, desse modo, da ocultação da escola literária nacional e popular da qual a Idade Média e o início do século XVI haviam dado exemplos admiráveis. Foram, portanto, os clássicos que, no início dos anos 1820, iniciaram a reabilitação dos poetas da Pléiade, concedendo a Ronsard pelo menos o papel de precursor do classicismo, por mais "bárbaro" que ele pudesse ser na língua e na versificação. As primeiras posições de Sainte-Beuve nos artigos que publica no Globe entre julho de 1827 e abril de 1828, e que constituem uma primeira versão de seu Tableau historique et critique de la poésie française et du théâtre français au XIX siècle [Quadro histórico e crítico da poesia francesa e do teatro francês no século XIX], são ainda relativamente prudentes: ele reconhece nas partes "originais" (ou seja, não subordinadas à imitação dos Antigos) da obra de Ronsard as marcas de um gênio "nacional", no qual os valores românticos e clássicos podiam ser reencontrados com certa facilidade. Mas depois que os clássicos ousaram qualificar os românticos de "Novos Ronsards", com o pretexto de que iriam, em nome do "Gênio" e contra o "Gosto", reconduzir a arte à barbárie, estes - tendo Hugo e Sainte-Beuve à frente logo relevaram o insulto para dele fazer um título de glória. E Ronsard podia então se tornar o porta-estandarte da revolução romântica: recrutado, em princípio, em nome da liberdade na arte, ele logo será, em nome do romantismo, artiste, quando Les orientales [As orientais] de Victor Hugo ou Josèphe Delorme de Sainte-Beuve terão reabilitado a imitação das formas do "Renascimento", como fará o próprio Nerval ao publicar, logo depois de seu Choix de 1830, algumas de suas Odelettes. ${ }^{2}$

A introdução de Gérard ao Choix de $1830^{3}$ se ressente das posições contraditórias que a obra de Ronsard cristalizou em torno dela, fazendo deslocarem-se as linhas da batalha romântica.

A argumentação geral é bastante retórica: um longo "Contra Ronsard (e sua escola)" precede um relativamente mais breve "A favor de Ronsard"; e essa sucessão de tese e antítese é coroada por uma síntese que leva em conta a diversidade da obra de Ronsard ao distinguir três aspectos do poeta do Vendôme: o poeta "pindárico", criticado por ser tão obediente à imitação dos autores antigos; o poeta "apaixonado e anacreôntico", apreciado porque, contra sua própria dou-

\footnotetext{
${ }^{2}$ Sobre as diferentes fases da redescoberta do Renascimento pelo romantismo ver, de Claude Faisant, Mort et réssurection de la Pléiade (1585-1828), Paris, Champion, 1998; "Métamorphose et signification d'un mythe critique", in Oeuvres et critiques, VI, 1, hiver 1981-1982, p. 9-16; e de Jean Céard: "La redécouverte de la Pléiade par les Romantiques français", in Pierre Brunel (org.), Romantismes européens et Romantisme français, Montpellier, Éditions Spaces, 2000, p. 133-148. Mais particularmente sobre o lugar de Nerval nessa redescoberta, ver, de Jean Céard, "Nerval et les poètes français du XVI siècle. Le Choix de 1830", RHLF, n. 84, p. 1033-1048, 1989; "Les débuts d'un seizièmiste: Nerval et l'Introduction aux poètes du XVI siècle", in Yvonne Bellenger (org.), La littérature et ses avatars, Paris, Aux Amateurs de Livres, 1991, p. 267-276.

${ }^{3} \mathrm{NPl}$, p. 281-301.
} 
trina, soube reatar vínculos com uma tradição francesa mais antiga, de graça e leveza; enfim, o poeta dos Discours, cujo alexandrino "forte e bem construído" anuncia o de Corneille tanto quanto o de Victor Hugo.

$\mathrm{Na}$ parte de sua dissertação "contra" a escola de Ronsard, Nerval permanece fiel às teses românticas que ele descobriu estudando a literatura alemã: toda grande literatura deve buscar renovação da inspiração retomando suas fontes nacionais e populares. Com Sismondi, com Schlegel, com Mme. de Staël, a doutrina romântica postula a existência de uma civilização "românica", antiga mas não da Antiguidade clássica, na qual a poesia de cada povo poderia beber novamente nas fontes de sua tradição particular, que a liberaria da imitação da Antiguidade. Ao longo de toda a sua reflexão sobre a arte, Nerval será fiel a essa tese: ele a defende em sua coletânea das Poésies allemandes de 1830; ele a ilustra novamente, no mesmo ano, em seu Choix de poesias do Renascimento; e voltará a ela ainda uma vez em 1842, quando realiza a coletânea das Vieilles Ballades Françaises [Velhas baladas francesas] com a intenção de restituir à poesia contemporânea a memória de seu próprio "romancero" nacional que, segundo ele escreve, foi esquecido na França por conta do classicismo, mas que permaneceu vivo na Espanha, na Alemanha e na Inglaterra. Essa defesa da literatura nacional e popular conduz Nerval a condenar, num primeiro momento, a escola de Ronsard, apoiando-se em Sainte-Beuve para atribuir a esta "e não a Malherbe" "o estabelecimento do sistema clássico francês". Para Nerval, a Pléiade teria cometido o erro de não acreditar nas "grande promessas" contidas nas poesias dos séculos XII e XIII, e de ocultar, em nome da Antiguidade (e mais, com uma espécie de "despotismo" doutrinal), a rica veia nacional da literatura cavaleiresca e gaulesa - sua única desculpa seria o fato de ter imposto sua visão num momento em que essa tradição francesa já havia se degenerado numa poesia de corte, toda feita de artifícios e de virtuosidades retóricas. Nesse discurso de acusação Nerval, mais do que Sainte-Beuve, cita longamente a Défense et Illustration de la langue française de Du Bellay, ressaltando nesse manifesto a nova escola o paradoxo que conduz Du Bellay a promover a dignidade poética da língua francesa ao mesmo tempo que a reduz à imitação dos gregos e latinos, de nada importando os "velhos autores franceses" que, no entanto, já haviam dado a ela seu valor literário.

Depois da acusação, vem a defesa da poesia francesa do Renascimento. Então Nerval muda sub-repticiamente de objeto, focando seu interesse menos na doutrina pela Pléiade (que ele condena) e mais nas próprias obras, que ele admira, e das quais fará uma abundante antologia, desvelando nos poemas uma prática da língua francesa que vai além do parti-pris da imitação da Antiguidade. Para Gérard-poeta, que logo em seguida será o poeta das Odelettes, é pelo "progresso do estilo e da cor poética" que a escola de Ronsard é grande. E em suas "pequenas odes", Ronsard, a despeito de tudo o que se diga, reata laços com "as canções do século XII", as quais ele até mesmo supera "em ingenuidade e em frescor". Há um "estilo primitivo e verdejante" em "Mignonne, allons voir si la rose..." ["Pequena, vamos ver a rosa"] de Ronsard, ou em "Avril" ["Abril"] de Belleau; e, em seu ritmo e sua prosódia, 
os poemas do Renascimento resgatam intuitivamente certo fraseado cantante da língua francesa, bem mais antigo - como aquele "francês tão naturalmente puro" ao qual Nerval será sensível nas canções do Valois, e que ele buscará recuperar no fraseado de alguns de seus versos, assim como no de algumas de suas prosas.

O Choix des poésies de Ronsard já é portanto rico de promessas, que o percurso poético de Nerval, fiel às suas primeiras intuições, tratará de cumprir, inflexionando-as numa direção pessoal.

Podemos de início atentar para o pensamento sobre a história que anima Nerval quando ele se debruça sobre o Renascimento: fazer de si, naquele momento, um historiador da poesia do século XVI - como fazer de si, noutro momento, o historiador de Angélique de Longueval, ou de alguns daqueles "illuminés" que se fazem presentes a cada século - não é apenas tentar exumar um passado esquecido, mas é também tentar garantir a continuidade dos tempos para além das fraturas provocadas por revoluções tão brutais. No plano literário, mas também político e religioso, é o classicismo, na França, qui institui a primeira dessas fraturas, e é portanto para algo anterior a ele que deve se voltar o olhar do historiador. A visão de Nerval é próxima daquela que Edgar Quinet irá desenvolver em sua Histoire de la Poésie: enquanto em todo o resto da Europa os desenvolvimentos mais brilhantes das literaturas nacionais residem na continuidade de suas formas primitivas, na França, o século de Luis XIV - que nisso aparece como "o primeiro ato das revoluções nas quais a França ira mobilizar o mundo", escreve Edgar Quinet ${ }^{4}$-, ao romper com o sistema feudal, rompe também com um conjunto de poesias e legendas das quais a Idade Média havia sido o berço, e cuja primeira manifestação literária havia sido possibilitada pelo Renascimento. Por detrás do gesto do historiador, que se coloca com tanto mais fervor diante do passado quando esse está separado dele por uma fratura que parece irremediável, revela-se um traço mais particularmente nervaliano: escrever o passado sempre será, para Nerval, tentar fazê-lo "renascer", ressuscitar, tirando-o dos limbos nos quais - como as figuras de sonho de Aurélia - ele teria sido recalcado. ${ }^{5}$

A reflexão de Nerval sobre os poetas do século XVI permite também compreender o pensamento sobre o língua no qual se reconhece o jovem escritor. Quando se debruça sobre a poesia do passado, Nerval é sensível à historicidade contida no fraseado dos poemas renascentistas e populares; mas ele não dissocia a historicidade da linguagem do pensamento sobre uma origem imemorial da língua - que se encarnaria idealmente (mas também de modo fantasmático) nessa velha "região do Valois onde por mais de mil anos bateu o coração da França". Nesse momento romântico da reflexão linguística, a questão da língua e de sua

${ }^{4}$ Edgar Quinet, "De l'histoire de la poésie [1857]", in Oeuvres complètes d'Edgar Quinet, t. IX, 1905, p. 418. (A Histoire de la poésie foi republicada por Éditions d'Aujourd'hui (Paris), Coleção "Les Introuvables", 1986.

${ }^{5}$ Ver, de Keiko Tsujikawa, Nerval et les nimbes de l'histoire. Lecture des "Illuminés". Genebra, Droz, 2008 (Prefácio de Jean-Nicolas Illouz). 
origem se encontra então situada entre mito e história - ainda no ponto de sua junção ideal, ou já no ponto de sua separação, precipitada pelo tempo. ${ }^{6}$

Acrescentaremos que esse pensamento sobre a língua, por se descobrir no contato com os poemas (e não apenas nos gestos de um historiador), é inseparável de uma atenção dada aos modos de sua enunciação, que a singularizam ao encarná-la numa voz, falante ao longo dos séculos. Essa atenção à voz conduzirá Nerval, como já foi dito, a reencontrar, por detrás de certo fraseado cantante do verso renascentista, as velhas baladas francesas e as canções populares. Mas ela explica também porque Nerval privilegia o Ronsard dos Discours, se assumirmos como verdade que o discurso implica uma prosódia que inscreve fortemente no verso a presença da enunciação. A qualidade dessa enunciação pode ser declamatória, em Ronsard; pode ser teatral, quando o alexandrino de Ronsard inspira o de Corneille, como aponta Nerval citando Schiller; mas ela também já é implicitamente nervaliana, pois, para além da ingenuidade cantante das Odelettes, os sonetos das Chimères [Quimeras] se caracterizam por uma forma de dramaturgia vocal - em que algo do alexandrino renascentista parece ressurgir em seu brilho originário. ${ }^{7}$

\section{Figuras do Renascimento e mitologia pessoal}

Para se chegar à poética das Chimères foi porém necessário que certa ideia do Renascimento, entrevista pela primeira vez por ocasião do Choix de 1830, amadurecesse longamente na criação de Nerval, a ponto de atrair para ela alguns dos nós nevrálgicos de seu imaginário.

A presença, no cap. III de Sylvie, de um relógio que parou em algum imutável balé das horas é suficiente para sugerir que o Renascimento de início alimenta, em Nerval, uma representação do tempo na qual a esperança de um eterno retorno das horas e das épocas viria contradizer o curso irreversível da temporalidade.

Ora, essa representação subjetiva do tempo se nutre de uma meditação erudita [savante] sobre o sentido que se deve atribuir, na história, à própria noção de Renascimento.

Para Nerval, assim como para certos historiadores contemporâneos, o Renascimento se reveste de um aspecto duplo: de um lado, ele aparece - em cada uma de suas manifestações (religiosa, política e artística) - como o primeiro dos grandes séculos críticos, que inicia o trabalho de solapamento do edifício feudal ${ }^{8}$

\footnotetext{
${ }^{6}$ Para colocarmos em perspectiva o pensamento linguístico de Nerval, podemos distingui-lo do de Mallarmé, estudado por mim num artigo intitulado "'Sur le nom de Paphos': Mallarmé et le mystère d'un nom", in Olivier Bivort (org.), La littérature symboliste et la langue. Paris, Garnier, 2009.

${ }^{7}$ Sobre a língua apreendida em seus diversos modos de enunciação, ver, de Henri Meschonnic, "Essai sur la poétique de Nerval", Europe, avril 1972, retomado em Pour la poétique III. Une parole écriture, Paris, Gallimard, 1973; e de Dagmar Wieser, "Nerval au miroir de Ronsard et de Corneille", in Laurent Adert e Éric Eigenmann (org.). L'Histoire dans la littérature. Genebre, Droz, 2000, p. 195-217. Sobre a dramaturgia vocal das Chimères, ver, de Jean-Nicolas Illouz, "La lyre d'Orphée ou le tombeau des Chimères", Littérature, n. 127, p. 71-85, sept. 2002.

${ }^{8}$ Cagliostro, NPl, p. 1119.
} 
que estaria destinado a chegar ao limite em 1789, e que desencadeia um processo de desencantamento do mundo destinado a acompanhar o advento da consciência moderna; de outro, e, digamos assim, como reação, o Renascimento é compreendido, literalmente, como um desejo de renascimento que garantiria a continuidade rompida das épocas e que equivaleria a uma palingenesia (social, religiosa e artística) em cujo termo "o homem material" das épocas modernas se veria "regenerar", tal como escreve Nerval no capítulo I de Sylvie, para evocar, no espelho do Renascimento, o romantismo de 1830.

Um exemplo é particularmente significativo: trata-se dos "neoplatônicos" de Florença, entre os quais Nerval inclui Marsílio Ficino, Pico della Mirandola, Nicolau de Cusa, Giordano Bruno, Campanella ou "o sábio Meursius". Notaremos a presença desses nomes tanto em Aurélia - quando Nerval se empenha em reconstruir a própria identidade, ameaçada de ser dominada pela loucura, quanto em Les illuminés [Os iluminados] (especialmente em Cagliostro), quando Nerval procura restabelecer as genealogias que, na escala da história coletiva, atestariam uma continuidade subterrânea ou oculta das ideias filosóficas e religiosas, quando essas atravessam pedíodos de crises e de revolução. É assim que o neoplatonismo florentino aparece como consequência de uma catástrofe histórica, a tomada de Constantinopla, que, ao exilar eruditos e filósofos "fez com que se estudassem novamente os Plotinos, os Proclos, os Porfírios, os Ptolomeus" na Itália, e reintroduziu no coração da Europa católica os "primeiros adversários do catolicismo nascente". 9 Jean Céard sugeriu que essa visão da história talvez tenha sido tomada de empréstimo da Histoire comparée des systèmes de philosophie [História comparada dos sistemas de filosofia] de Joseph-Marie Gérando (1847). ${ }^{10}$ Bertrand Marchal notou, por sua vez, que esse paganismo renascentista é na verdade um paganismo duplamente renascente, ${ }^{11}$ pois toma emprestadas as formas de sua espiritualidade não diretamente da Grécia, mas da Alexandria, ou, como nota Nerval em Isis, o paganismo helênico já havia se regenerado ao "embeber-se novamente em sua origem egípcia", e já havia se depurado ao tentar "reconduzir ao princípio da unidade as diversas concepções mitológicas". ${ }^{12}$

Em Quintus Aucler, para descrever essa palingenesia religiosa que faz voltar gradativamente as formas mais antigas da espiritualidade, Nerval propõe a imagem do "palladium místico", passando de Bizâncio a Florença, depois de ter passado da Grécia a Troia, de Troia a Roma, e de Roma à Alexandria:

A nova aspiração pelos deuses, depois de mil anos de interrupção de seu culto, não começou a se mostrar no século XV, antes mesmo que, sob o nome de Renascimento, a arte, a ciência e a filosofia se renovassem pelo sopro inspirador de Bizâncio? O "palladium mistico", que havia

${ }^{9}$ Idem, ibidem, p. 1124.

${ }^{10}$ Jean Céard, "Nerval et la Renaissance", RHLF, n. 4, p. 805-815, 2005.

${ }^{11}$ Bertrand Marchal, "Nerval et le retour des dieux ou le thèâtre de la Renaissance", in Gérard de Nerval, Les Filles du feu, Aurélia. Soleil noir, Paris, Sedes, 1997, p. 125-132.

${ }^{12}$ Isis, NPl III, p. 619. 
até então protegido a cidade de Constantinopla, iria se romper, e já a nova semente fazia saírem da terra os gênios aprisionados do velho mundo. Os Médici, ao acolher os filósofos acusados de platonismo pela inquisição de Roma, não fizeram de Florença uma nova Alexandria? ${ }^{13}$

O recuo no tempo, pelo qual as religiões se renovam alimentando-se novamente em suas origens arcaicas, é acompanhado de uma série de deslocamentos no espaço: de Alexandria a Bizâncio, de Bizâncio (ou Constantinopla) a Florença e, finalmente, de Florença à França e ao Valois - Nerval se apoia na realidade histórica, que associxa enfim os Médici aos últimos Valois, para desviar e prolongar o curso da história universal segundo os contornos fabulosos de sua "fantasmática" pessoal.

Pois o Valois é mesmo o ponto de concreção geográfico no qual os dados históricos se fundem muito intimamente ao mito pessoal.

Com efeito, a aliança entre os últimos Valois e os Médici transpôs para a Île de France - para essas terras "que faziam parte dos antigos apanágios de Marguerite de Valois e dos Médici" - certo "ar de Itália" que Nerval, em Angélique, não deixa de apontar. Esse ar pode ser sentido até nas "brumas transparentes e coloridas dessa região", onde Watteau encontrou os tons de sua Voyage à Cythère, ela mesma uma retomada d'O sonho de Polifilo, antes concebido na Itália ensolarada de Francesco Colonna. A época dos Médici deixa sua marca na abadia de Châalis, onde se respira um "perfume de renascimento", e cujas abóbadas pintadas têm "ares de alegoria pagã que lembram as sentimentalidades de Petrarca e o misticismo fabulosos de Francesco Colonna". ${ }^{14}$ Até mesmo a língua dos camponeses misturaria ao "francês tão naturalmente puro" do Valois medieval o mais melodioso fraseado italiano do Valois renascentista:

A língua dos próprios camponeses é o mais puro francês, um pouco modificado por pronúncias e desinências de palavras que se elevam até o céu à maneira do canto da cotovia. Nas crianças isso forma como uma ramagem. Há também no torneio das frases algo de italiano - o que sem dúvida se deve à longa permanência dos Médici e seu séquito florentino nessas terras, outrora divididas em apanágios reais e principescos. ${ }^{15}$

O Valois nervaliano consegue assim conservar, numa unidade viva, perceptível até nas ruínas que por ele se espalham, os diferentes estratos temporais que fizeram sua história, e que parecem transparecer uns sob os outros em infinitos jogos de espelhamentos.

Percebemos assim o sentido mais profundo das peregrinações nervalianas: se é verdade que, para Nerval, o Valois é o lugar de um renascimento ansiado, isso não se dá apenas por ser ele a terra de suas origens maternas, garantia de um possível renascimento pessoal, mas por ser também aquela região da França onde

${ }^{13}$ Quintus Aucler, NPl II, p. 1159.

${ }^{14}$ Angélique NPl III, p. 487, p. 503; e Sylvie, NPl III, p. 552.

${ }^{15}$ Angélique, NPl III, p. 477. 
o Renascimento histórico se encarnou por algum tempo e onde a História poderia então novamente "trazer de volta a ordem dos antigos dias", tomando a forma de uma paligenesia da humanidade e do sagrado. O palladium mistico, que reapareceu uma primeira vez na Alexandria, e depois em Constantinopla e em Florença, prossegue aqui sua errância nessa nova terra de exílio, à qual o promeneur chega partindo de Paris "que traz em suas armas a bari ou a nau mística dos egípcios"16 e passando por diversos lugares indissociavelmente ligados ao Renascimento histórico e à história pessoal: em especial Saint-Germain, "a cidade dos Stuart", cuja "Diana do Valois" evoca ao mesmo tempo a Diana de Poitiers e a lembrança de algum primeiro amor, ${ }^{17}$ mas também Saint-Denis, cuja Basílica abriga o túmulo de Catarina de Médici. Esse é descrito no início de Quintus Aucler, e Nerval nele ressalta aquele estilo renascentista marcado por uma graça cuja inocência não está isenta de violência subversiva: os anjos e os santos da religião cristã se misturam a figuras das religiões pagãs - as três Graças, os dois amores Eros e Anteros - assim como a própria Catarina de Médici, jazendo ao pé de Henri II, parece Citereia ao pé do "Adonis dos mistérios da Síria", mas também Vênus e, mais ainda, Artêmis, assim como a Virgem Maria recolhendo o "Cristo despregado da árvore mística". Na imaginação de Nerval, Catarina de Médici, como bem notou Bertrand Marchal, se confunde então com Aurélia e aparece como uma hipóstase da mãe biográfica, assim como da Mãe divina. Uma e outra seriam assim eternamente renascentistas, se a história - e se o próprio Renascimento - não prosseguissem sua obra destruidora, pois, na Basílica de Saint-Denis, as portas que são empurradas pelo narrador aparecem igualmente como "portas sombrias aberta para o nada". ${ }^{18}$

\section{Poéticas renascentistas}

Se o Renascimento nutre o imaginário e a fantasmática de Nerval, ele ocupa também uma posição singular na consciência que o escritor toma de sua arte - e é significativo que em 1852 (mais de vinte anos de distância), Nerval retome sua Introduction au Choix de 1830 em La Bohème Galante - que é ao mesmo tempo uma narrativa de recordações pessoais e a narrativa da vocação literária de um poeta e de um prosador.

\section{Odelettes cantantes e sonetos supernaturalistas}

Quanto à vertente em prosa da criação nervaliana, Jean-Luc Steinmetz mostrou que a antologia de 1830, pelas escolhas que opera e pelas afinidades que revela, já balisa toda a produção ulterior de Nerval assinalando, no Renascimen-

\footnotetext{
${ }^{16}$ Promenades et souvenirs, NPL III, p. 687.

${ }^{17}$ Pandora, NPL III, p. 656.

${ }^{18}$ Quintus Aucler, NPl II, p. 1135-1138.
} 
to, o berço de sua "dupla poesia" - a das odelettes ingênuas e cantantes, assim como aquela, tão dessemelhante à primeira vista, dos sonetos alucinados ou "supernaturalistes". 19

A filiação das Odelettes à poesia do Renascimento é evidente, pois o próprio Nerval apresenta algumas de suas Odelettes como uma ilustração de sua primeira maneira poética, diretamente influenciada pela voga recente de Ronsard e sua escola: "Nessa época, eu ronsardizava", escreve ele, retomando uma palavra de Malherbe. ${ }^{20} \mathrm{~A}$ imitação é claramente visível nos temas escolhidos para essas pequenas composições: Avril retoma um título de Belleau e fala da espera por um reverdecer da natureza; Gaieté [Alegria] é uma pequena ode aos vinhos da França, à maneira dos fantasistas báquicos do século XVI... mais profundamente, e indo além dos temas, a inspiração no Renascimento está contida na própria memória da forma da odelette: Les Papillons [As borboletas] retomam o esquema métrico e estrófico de Bel Aubépin de Ronsard, d'Avril de Belleau, passando sem dúvida pela intermediação de outros poetas românticos que já haviam trazido novamente ao gosto do dia as combinações métricas da Pléiade, como À la rime [À rima] de Sainte-Beuve (em Vie, poésies et pensées de Joseph Delorme [Vida, poesias e pensamentos de Joseph Delorme], 1829), ou Sara la baigneuse [Sara, a banhista] de Victor Hugo (em Les Orientales, de 1828). Mas a memória da forma se aprofunda na escrita de Nerval e, indo além da métrica aprendida, ela permite alcançar certo fraseado da língua, popular e francês, ingênuo e cantante. De tal modo que, assim como Ronsard que, em suas "petites odes", retomava as canções do século XII para além da imitação acadêmica da Antiguidade, assim também Nerval, em suas Odelettes, reencontra, para além da imitação do Renascimento, um ar mais antigo: aquele de que as Chansons du Valois são a figura privilegiada, e que corre, quase inapreensível, na poesia em verso de Nerval, assim como em sua poesia em prosa. ${ }^{21}$

É por uma via bem diferente, mas com a mesma justeza, que os sonetos das Chimères (e do "ateliê" das Chimères) se vinculam ao Renascimento, revelando um aspecto bem diverso da poesia do século XVI: não mais a poesia transparente, ingênua, com uma dicção imediatamente cantante, mas uma poesia hermética, marcada por certa grandiloquência, declamatória em sua elocução.

Esses dois aspectos coexistem em Ronsard; mas o segundo aspecto - mais "barroco" do que "pré-clássico" - aparece com toda força num Bartas que Nerval inclui em seu Choix de 1830. Ora, Nerval invoca diretamente de Du Bartas num

19 Jean-Luc Stenmetz, "La double poésie de Gérard de Nerval”, in Reconnaissances. Nerval, Baudelaire, Lautréamont, Rimbaud, Mallarmé, Nantes, Éditions Cecile Defaut, 2008, p. 21-50.

${ }^{20}$ La Bohême galante, NPl III, p. 264.

${ }^{21}$ Sobre as Odelettes, ver, além da nota da edição da Pléiade (NPI, p. 1623-1628), Jean-Luc Steinmetz, "Les poésies dans les Petits châteaux de Bohême", in Signets. Essais critiques sur la poésie du XVII et XXe siècle, Paris, Corti, 1995, p. 71-86. 
soneto surpreendente, analisado por Jean-Luc Steinmetz: ${ }^{22}$ numa carta a Victor Loubens de 1841, ele traz o título de Tarascon, e é também conhecido pelo título-dedicatória de À Mme. Sand da versão do manuscrito Dumesnil de Gramont $\alpha$. Depois de haver transcrito (não sem fazer algumas modificações) o primeiro quarteto de um soneto de Du Bartas tirado de Neufs muses pyrénées [Nove musas dos Pirineus], Nerval concatena diretamente com os versos:

\author{
Ô seigneur Du Bartas! Je suis de ton lignage \\ Moi qui soude mon vers à ton vers d'autrefois [...] \\ [Ó senhor Du Bartas! Sou de tua linhagem \\ Eu que soldo meus versos em teu verso de outrora]..$^{23}$
}

A dívida com o Renascimento toma a forma da proclamação de uma "linhagem" pela qual Nerval se inscreve na descendência sonhada de Du Bartas, e pela realização de uma "soldagem" mediante a qual o verso de Nerval retraça, com efeito, o sulco do verso de Du Bartas. Jean-Luc Steinmetz lançou luz sobre as implicações fantasmáticas e poéticas dessa montagem intertextual (ou, poderíamos dizer, dessa atrelagem poética de um novo gênero). Não retomaremos esse belo estudo senão para assinalar o quanto o verso, como versus, como retorno, como esquema rítmico memorial, perfaz aqui, por si só, certa ideia de renascimento - a respeito da qual é preciso notar aqui que ela se impõe a Nerval no momento de sua primeira crise de loucura: pela eficácia poética da encantação, é Du Bartas que "renasce" em Nerval, encarna-se em sua voz - como se o verso pudesse suspender "a ordem do tempo" fazendo ressoar na língua a imensa memória intertextual, toda ela "concentrada" no instante, fora do tempo, em que é proferida.

\title{
Prosa fantasista e prosa alegórica
}

Perceptível nos verso de Nerval, o duplo aspecto da poesia renascentista se imprime também no duplo aspecto que assume sua prosa - ora fantasista, ora mística - "realista", por um lado, alegórica e poética, por outro.

A veia "fantasista" ou "realista" está ilustrada particularmente em Les faux saulniers, Les nuits d'octobre ou Angélique. É uma outra linhagem que reivindica

22 Jean-Luc Steinmetz, "Un disciple de Du Bartas: Gérard de Nerval", in Signets, op. cit., p. 87-106.

${ }^{23}$ Manuscrito Dumesnil de Gramont $\alpha$, NPL I, p. 734; carta a Victor Loubens, de fim de 1841, NPl III, p. 1490; pode-se ler uma outra versão desse poema, sem a estrofe inicial de Du Bartas, numa carta de Nerval a George Sand de 22 de novembro de 1853, NPl III, p. 824-825. Nerval cita o soneto de Du Bartas tirado de Neufs Muses Pyrénées em seu Choix des Poésies de Ronsard [...], Paris, Bibliothèque choisie, 1830, p. 212. Para realizar sua antologia de poemas de Du Bartas, ele consultou a edição de 1615 das Oeuvres poétiques et chrestiennes de G. De Salustes, Du Bartas, prince des poëtes françois, na qual se pode ler, ao fim do volume, anotado com a letra de Nerval, a seguinte anotação: "Este livro foi inteiramente lido por Gérard em mil oitocentos e trinta". 
então Nerval, pois ele próprio se inscreve numa série de prosadores "excêntricos" que passa por Diderot, Sterne, Swift no século XVIII, que remonta a Petrônio ou Luciano, no que diz respeito aos autores antigos, e que, no Renascimento, se encarna em Rabelais, Merlin Cocai ou ainda em Erasmo... Reconhece-se imediatamente a maneira de ser dessas narrativas: alerta ou fantasiosa, pitoresca ou picaresca, digressiva e rapsódica, irônica assim como melancólica, de todo modo sempre subjetiva até mesmo no relato fiel das impressões (de viagem, de errância, de divagação), ela faz de Nerval "um prosador enérgico" 24 que, desde um artigo de 1836, definia a si mesmo como um "escritor frívolo, mas não um escritor fácil"...25

A outra face de Nerval prosador - a do "sonhador em prosa" 26 - se revela em Sylvie ou em Aurélia. Aqui a prosa se alia ao modelo da fábula mística e da narrativa iniciática, tendo como modelos sucessivos ou "patronos" literários Apuleio, ... Dante..., sem dúvida alguns "iluminados".., Goethe e os românticos alemães..., mas também, no Renascimento (que serve mais uma vez de pivô principal), Francesco Collona, mais particularmente.

A obra de Francesco Colonna, a Hypnerotomachia Poliphili, adaptada para o francês por Jean Martin com o título de Le songe de Poliphile [O sonho de Polifilo], acompanha por muito tempo o devaneio nervaliano e nutre sua criação. Na lista de suas Oeuvres complètes estabelecida algum tempo antes de sua morte, Nerval menciona, na rubrica "Temas", um Francesco Colonna, acompanhado da menção "com Lucas";27 cartas de 1853 atestam que ele teria mesmo imaginado uma peça com Hyppolyte Lucas que combinaria elementos de A flauta mágica, de Aurora ou la fille de l'enfer [Aurora ou a filha do inferno] (uma comédia de Von Söden adaptada do alemão por Boursault-Malherbe) e do Songe de Poliphile (possivelmente na adaptação de Legrand), ${ }^{28}$ - mais um exemplo, dessa vez na prosa, da hibridação intertextual que preside em Nerval a composição das obras-quimeras.

O Sonho de Polifilo é, para Nerval, uma maneira de se comunicar, para além da morte, com o "bom Nodier", na medida em que Nodier, considerado pelo autor de Angélique [Nerval] como seu "tutor literário", ${ }^{29}$ compôs ele mesmo, no fim de sua vida (1844), um Franciscus Columna, legando a Nerval seu próprio devaneio erudito e bibliofílico sobre o Renascimento.

É em princípio como bibliófilo que Nerval admira o livro de Colonna. Considerada uma obra-prima tipográfica do Renascimento, a obra é ilustrada, na edição de Albe (Veneza, 1499), por xilogravuras da Escola de Mantegna, e na edição francesa publicada por Kerver (Paris, 1546), por gravuras de Jean Goujon inspi-

${ }^{24}$ Carta a Alexandre Dumas, NPl III, p. 826.

${ }^{25}$ Le Carroussel, fim de março de 1836, NPl I, p. 342.

${ }^{26}$ Promenades et souvenirs, NPl III, p. 681. Ver, de Jean-Nicolas Illouz, Nerval. Le "rêveur en prose". Imaginaire et écriture. Paris, PUF, 1997 ("Écrivains").

27 [Projet d'] Oeuvres complètes, NPl III, p. 786.

${ }^{28}$ Lettre à Hippolyte Lucas, março ou abril de 1853, NPl III, p. 801.

${ }^{29}$ Voyage en Orient, NPl II, p. 237, e Angélique, NPl III, p. 475. 
radas nas xilogravuras originais, transportando (ao que Nerval certamente foi sensível) as paisagens áridas da Itália para a verdejante Arcádia dos jardins da França. Uma primeira afinidade entre Le songe de Poliphile e Sylvie se revela nesse ponto, pois podemos supor que a preocupação de Nerval de acrescentar ilustrações a Sylvie (sobre a qual ele escreve numa carta de 1853 a Maurice Sand) é motivada pela lembrança das gravuras que adornam a obra de Colonna - Sylvie aparecendo, à semelhança de Poliphile, como um livro-objeto, - com a diferença de que aquilo que na obra de Colonna glorificava as maravilhas da imprensa, corre o risco, com Nerval, a apontar para a obra de um daqueles "loucos literários" (que são com frequência escritores-tipógrafos), já listados por Nodier e pelo próprio Nerval em Les Illuminés (como aquele Raoul Spifame apaixonado pela imprensa do tempo de Luís II) e, indo além, por Raymond Queneau, que reunirá seus próprios loucos literários sob o nome nervaliano de "filhos do limo"...

Em Voyage en Orient, no momento de abordar (pelos livros apenas) a ilha de Citera, Nerval desvela algumas das razões espirituais que o ligam ao livro de Colonna. Le songe de Poliphile lhe aparece como um exemplo maravilhoso daquelas obras pelas quais o Renascimento, sob a influência dos neoplatônicos de Florença, garante uma sobrevida ao paganismo no cristianismo mediante a elaboração artística e filosófica de um novo sincretismo. Porém, analisando (de uma maneira bastante livre em relação ao original) Le songe de Poliphile, Nerval entrevê na fábula de Colonna motivos amorosos e religiosos que já se ligam, como ele escreverá em Sylvie, a "preocupações constantes": ${ }^{30}$ Polifilo e Polia, proibidos de se casar na Igreja pela desigualdade de suas condições, unem-se sob os auspícios de Eros e Afrodite; eles aceitam ser separados na vida para se reunirem após a morte - e, "algo bizarro", acrescenta Nerval, "foi sob as formas da lei cristã que eles cumpriram esse voto pagão". Após uma longa glosa que destaca a continuidade dos símbolos pagãos no culto cristão, Nerval, que além do mais aproxima Le songe de Poliphile do Fausto de Goethe (outro exemplo da multiplicação de níveis intertextuais característica da criação nervaliana), imagina que Polifilo e Polia, tendo ambos se tornado religiosos, reúnem-se em sonho - descobrindo, como o herói de Sylvie, "as santas moradas de Citereia", onde suas homenagens aos deuses pagãos, "indo atingir os céus longínquos e desacostumados de nossas preces", reencantam o mundo e celebram a harmonia reencontrada entre a natureza, o homem e o sagrado. ${ }^{31}$

Nesta análise, Le songe de Poliphile já se tornou a trama de uma fábula poética, de certo modo arquetípica, na qual a narrativa de Sylvie desenha seus próprios bordados.

Encontramos em Sylvie duas referências explícitas à obra de Colonna: a primeira, já mencionada, aparece no capítulo VII, quando se trata de evocar os afrescos da abadia de Châalis, e seus "ares de alegoria pagã que fazem lembrar as sentimentalidades de Petrarca e o misticismo fabuloso de Francesco Colonna"; a segunda

\footnotetext{
30 Sylvie, NPl III, p. 565.

${ }^{31}$ Voyage en Orient, NPl II, p. 235-240.
} 
aparece no capítulo XII e se vincula ao drama que o narrador começa a compor ("eu havia começado a fixar numa ação poética os amores do pintor Colonna pela bela Laura, transformada em religiosa pelos pais, e que ele amou até a morte"32). Nos dois casos, Nerval associa ou confunde Colonna e Petrarca (ou Polia e Laura), apontando assim para os dois aspectos que assume, a seus olhos, o Renascimento; "sentimental", por um lado, "místico por outro", e que se encontram ambos, com efeito, em Sylvie.

Outros traços do Polifilo, mais implícitos, são igualmente perceptíveis em Sylvie: como num palimpsesto, pode-se adivinhá-los na prosa demasiado transparente de Nerval, pela série de níveis intertextuais que a novela dispõe num efeito de espelhamento [mise en abyme]. É assim que o capítulo IV, Uma viagem a Citera, retoma, pelo prisma de Watteau, um dos episódios principais de Le songe de Poliphile, e certos detalhes dessa cena são como points de capiton ${ }^{33}$ que assinalam no tecido do texto a emergência mais precisa do "original resplandecente" ${ }^{34}$

Além das afinidades temáticas entre as duas obras, o modo de composição é também comparável. Em Sylvie, assim como no Polifilo, o sonho se incrustra no sonho e, como no Poliphile, a divisão implícita em duas partes permite extrair, de uma a outra, ensinamentos do sonho, ainda que, no Poliphile, a segunda parte conduza a uma elucidação feliz dos sonhos, ao passo que, em Sylvie, a segunda parte impõe a constatação de um divórcio entre o sonho e a realidade, e finalmente marca o fracasso da narrativa iniciática. Do mesmo modo, parece que Nerval encontra no Poliphile o modelo da narrativa com duas intrigas estreitamente ligadas e, ao mesmo tempo, o modelo de uma fábula com dois níveis de sentido: como no Poliphile, o protagonista de Sylvie persegue, por uma dupla busca amorosa - a de Sylvie, comparada a uma "ninfa antiga" - e a de Adriana, que se tornou uma religiosa, uma dupla busca espiritual, por um lado, cristã, por outro, pagã "as duas metades de um único amor" sendo assim as duas metades de uma mesma esperança religiosa, colocada aqui na imanência (próxima de Sylvie), e acolá na transcendência (próxima de Adrienne). As semelhanças entre as duas obras não são de tal ordem que as diferenças deixem de assinalar uma disfunção nos jogos da reescrita: o que estava estreitamente unido na figura de Polia se cinde em dois na novela de Nerval, que não consegue tão bem quanto seu modelo renascentista atar o nó borromeano ${ }^{35}$ que poderia enlaçar cristianismo e paganismo, e que não consegue fazer coincidir as duas faces dessa estranha fita de Möbius tecida pela dupla intriga da narrativa - consagrada no recto, à expressão do "ideal sublime" e do amor cristão.

Enfim, Sylvie recobre uma dimensão autobiográfica implícita cujo modo peculiar poderia idealmente decorrer de seu modelo renascentista. Com efeito, aos

\footnotetext{
32 Sylvie, NPl III, p. 552 , e p. 565

${ }^{33}$ Conceito lacaniano. (N.T.)

${ }^{34}$ Sylvie, NPl III, p. 543.

35 Conceito lacaniano. (N.T.)
} 
olhos de Nerval, Le songe de Poliphile é uma fábula autobiográfica, em que Francesco Colonna teria transposto a história de seu amor para a história do amor de Polifilo e Polia - e esse amor escondido na vida está também escondido no texto, pois uma espécie de acróstico, notado por Nodier e por Nerval, revela ao leitor a confissão indireta: ao ligarmos entre si as letras do início de cada capítulo, descobrimos a seguinte legenda: Poliam frater Franciscus Columna peramavit [irmão Francisco Colono amava Polia intensamente] ${ }^{36}$ Pode-se perceber uma transposição semelhante da vida para a obra em Sylvie ("um pequeno romance que não é inteiramente um conto" ${ }^{37}$ ), em cuja fábula Nerval "recompõe" a lembrança de certa Jenny Colon amada e perdida,-- assim como o nome Colonna basta, como atesta o manuscrito dedicado A J-Y Colonna, para evocar, numa forma italianizada, o nome da atriz... ${ }^{38}$

Essas múltiplas concordâncias entre as duas obras não fazem senão tornar mais perceptíveis as divergências, que o trabalho de reescrita também revela. E entre Sylvie e seu modelo renascentista, é a própria possibilidade da transposição alegórica que se vê abalada.

Em Le songe de Poliphile, a alegoria atua em dois níveis: no plano da fábula, ela permite conceber o sonho como uma "porta de chifre" que possibilita ao personagem atravessar a sylve obscure na qual ele em princípio se perdeu para alcançar, ao cabo de uma série de provas qualificantes, a uma revelação luminosa, em que Polia aparece como a fonte de todo o amor e sabedoria; no plano de relação entre a obra e a vida, a alegoria permite ao autor decifrar sua própria vida, não mais considerando-a simplesmente em sua realidade anedótica, mas interpretando-a no sentido mais elevado, transposta para uma mitologia e uma mística pessoais, elucidada em sua verdade "poética". Por isso a maneira característica "livro de memória" renascentista, em que cada coisa é ao mesmo tempo evidente e misteriosa, secreta e transparente - à imagem, com efeito, da prosa nervaliana.

Mas, em Sylvie, a alegoria perde sua eficiência nos dois níveis, momentos em que sua intervenção deveria ser crucial.

No plano da fábula, o sonho, em vez de iluminar a vida, revela-se, no capítulo VII, nada mais do que "talvez uma obsessão". No plano da relação entre a obra e a vida, o narrador, intervindo diretamente no capítulo XIV, constata o fracasso de sua narrativa em ser algo mais do que a narrativa de uma "experiência"; e Sylvie, que ele acaba de escrever, lhe aparece então como uma obra qua já não é alegórica, à maneira das fábulas autobiográficas renascentistas, mas "realista", na medida em que a vida se vê no fim das contas reduzida à sua única dimensão, privada da aura dos mitos e do sagrado, sem relevo "poético".

Aurélia, tomando como molde (entre outros) a Vita Nuova (entre outros) de Dante (com as mesmas insuficiências), revelará mais ainda essa insuficiência

\footnotetext{
${ }^{36}$ Voyage en Orient, NPl II, p. 240.

${ }^{37}$ Carta a Maurice Sand, 5 novembro 1853, NPl III, p. 819.

${ }^{38}$ À J-Y Colonna, NPl I, p. 733.
} 
da alegoria na leitura dos sonhos e na decifração de si mesmo. Das primeiras às últimas linhas, a narrativa hesita entre a fábula iniciática e o relato clínico das diferentes fases de uma "doença", sem que Nerval consiga conciliar o duplo olhar, ora poético, ora realista, que ele lança conjuntamente sobre si mesmo.

O desfecho então já não pertence à obra; e o significante se revela como algo que age tão perigosamente sobre a existência que Nerval, que assinou uma de suas cartas delirantes com o nome de "Phénix", sempre renascente, ou com o nome d' "aquele que foi Gérard e que ainda o é", 39 irá buscar tragicamente na noite preta e branca o segredo incerto de um outro renascimento.

Tradução de Marta Kawano, do texto original em francês "Nerval, poète renaissant".

${ }^{39}$ Carta a Paul Bocage, 14 março 1841, NPl I, p. 1376; carta a Arsène Houssaye, 12 março 1841, NPl I, p. 1375. 